\title{
DEVELOPMENT OF STUDENTS' INNOVATIVE COMPETENCE IN UNIVERSITY STUDIES OF SOCIAL SCIENCES, APPLYING INDUSTRY-BASED TECHNOLOGIES'LEARNING RESOURCES
}

\author{
Andreas Ahrens ${ }^{1}$, Julija MelniKova ${ }^{2}$, Jel̦enA ZAŠČERINSKA ${ }^{3}$ \\ Hochschule Wismar, University of Applied Sciences, Technology, Business and Design (Germany), \\ Klaipėda University (Lithuania), Centre for Education and Innovation Research (Latvia)
}

\begin{abstract}
The purpose of this article is to highlight the aspects of application of Fast Track Solution SAP Business One Model to the business curriculum of a university study programme. With the SAP Business One, students gain knowledge and understanding on how different areas of business interact and integrate and how information technology-based infrastructure simplify business operations. In addition, this research article introduces and identifies the SAP Business One modules that can be applied to the present business curriculums of university studies, which leads to a blended learning approach when education addresses the needs of industry. Blended learning, as a learning approach that applies the SAP Business One modules, complements the skills required by industries thus fostering the industry-based learning approach. Theoretical knowledge and hands-on experience will make business students gain competitive advantage and competency in innovativeness.

KEYWORDS: SAP Business One Model, business curriculum, industry-based learning approach, blended learning.
\end{abstract}

JEL CODES: M10; M15; I25

DOI:

\section{Introduction}

In general, innovation is recognised as a key factor in economic competitiveness of the modern society, whereas in Lithuania and Latvia in particular. The important role of higher education in promoting more innovative attitudes and behaviours now is widely discussed. Therefore, it is very important for Lithuania and Latvia, which are currently moving towards the innovation-driven society model and are seeking to rearrange their educational systems. According to Lisbon strategy for growth and employment, universities need to stimulate the entrepreneurial mindsets of young people, encourage innovative business start-ups,

1 Andreas Ahrens - Prof. Dr.-Ing. habil. Hochschule Wismar, University of Applied Sciences, Technology, Business and Design, Wismar, Germany. Faculty of Engineering, Department of Electrical Engineering and Computer Science Address: Philipp-Müller-Straße 14, 23966 Wismar, Germany

Scientific interest: ICT in higher education

E-mail: andreas.ahrens@hs-wismar.de

Phone: +4903841 753-7330

2 Julija Melnikova - Klaipéda University, Faculty of Humanities and education Sciences, Klaipėda, Lithuania

Address: S. Nèries Str. 5, LT-92227 Klaipèda, Lithuania

E-mail: julija.melnikova@ku.lt

Phone: +370 46398 616; Fax +370 46398602

Scientific interest: Education management

Jeḷena Zaščerinska - Centre for Education and Innovation Research, Riga, Latvia

Address: Dammes iela 33-102, LV-1069 Riga, Latvia

Scientific interest: Interdisciplinary approach to adults' education

E-mail: ceir2012@gmail.com

Phone: +37129435142 
and foster a culture that is friendlier to entrepreneurship. Consequently, higher education in Lithuania and Latvia is confronted with demands to adapt learning environments and teaching practices to foster students' creativity, innovative skills and entrepreneurship.

The tendency stressed by comparative research data (Entrepreneurship in Latvia and other Baltic Countries, 2013; Entrepreneurship in Education in Baltic Sea Region, 2015) is that Lithuania's and Latvia's universities and higher education system on the whole should take steps toward changing their classic role, which was merely producing knowledge, towards entrepreneurship universities, which produce knowledge, create ideas and also transfer them into action in alignment with local, regional and international economic development. Hence the question arises: how these skills can be developed through education? The knowledge about this is limited due to lack of methodical approaches. This puts emphasis on university teachers to rethink and improve approaches to learning and innovate teaching pedagogy for to enhance students' skills and abilities towards productive, active and applied learning.

One of the approaches that fosters students' employability and entrepreneurship skills is industry-based learning. In order to fulfil the increasingly competitive job market, universities have to prepare and equip their graduates with necessary skills and practical working knowledge. Industrial oriented methodology is an approach to learning from an industry perspective. Technology is directly linked to industry and has a profound impact on education and the learning process. It is expected that the integration of university teaching-learning approaches and technology as well as new forms of augment reality will transform the way students learn. Training and educational programs will gain the blended format, which combines traditional face-to-face learning with new forms of technology assisted learning (Iniguez, 2016).

This paper has been prepared within the project Hochschulkooperation "Energy Efficiency in Southern Africa" supported by Bundesministerium für Bildung und Forschung in Germany, that was specifically aimed at developing a theoretically grounded model of digitalisation of university study programmes. The current study aims to assess the applicability of the Fast Track Solution SAP Business One Model to the business curriculum of a university based on the example of Hochschule Wismar experience in digitalisation of study modules. Also, the authors aim to implement the received results in the universities of Lithuania and Latvia. SAP Business One is business management software (enterprise resource planning) designed for small and medium size enterprises, and covers different areas of business which include:

(a) Accounting and Finance;

(b) Sales and Customer Relationship Management;

(c) Purchasing and Operations;

(d) Inventory and Distributions;

(e) Reporting and Administration.

With SAP Business One, students gain knowledge and understanding on how different areas of business interact and integrate and how information technology-based infrastructure simplify business operations. The integration and synchronization of different areas of business is made possible by the enterprise resource planning environment that maximizes company resources by addressing bottlenecks in the operations.

In addition, this research article introduces and identifies the applicable SAP Business One modules to the present business curriculum of university studies. It leads to a blended learning approach characterised by reinventing education that seeks to address the needs of industry. Blended learning as a learning approach that applies the SAP Business One modules complements the skills required by industries. Theoretical knowledge and hands-on experience make business students gain competitive advantage and competency in innovativeness.

In research, a case study has been applied as "case studies $[\ldots]$ are generalizable to theoretical propositions and not to populations or universes. In doing a case study, researcher's goal will be to generalize theories (analytical generalization) and not to enumerate frequencies (statistical generalization)" (Yin, 2003: 10). The case study research is a qualitative research design (Kohlbacher, 2005). Moreover, an exploratory type of the case study research has been employed in this empirical study (Zainal, 2007), because case studies 
have an important function in generating new research questions, hypotheses and building theory (Kohlbacher, 2005). Exploratory case studies are set to explore any phenomenon in the data, which serves as a point of interest to the researcher (Zainal, 2007). The exploratory methodology proceeds from exploration in Phase 1 through analysis in Phase 2 to hypothesis/research question development in Phase 3 (Ahrens, Bassus, Zaščerinska, 2013: 104).

The empirical study was carried out at Hochschule Wismar in Germany, in March 2017. The relevant information of the Wismar Hochschule business curriculum adopting blended learning curriculum was used as the raw data in the study.

Furthermore, in this research study, the interpretive paradigm was used. The interpretive paradigm aims to understand other cultures, from the inside through the use of ethnographic methods such as informal interviewing and participant observation, and establishment of ethically sound relationships. The interpretative paradigm is characterised by the researcher's practical interest in the research question (Cohen, Manion, Morrison, 2003). The researcher is the interpreter.

\section{Blended learning as an industry-based teaching-learning approach}

Traditional classroom practices call for instructor-led unidirectional learning where today's generation students may find it unproductive, thus losing their interest in rendering their skills undeveloped. This implies the necessity for university teachers to re-consider and advance approaches to learning and innovate teaching pedagogy so that to enhance students' skills and abilities towards productive, active and applied learning.

Technology has and will continue to have a profound impact on education and the learning process. It is expected that the symbiosis between higher education didactics and technology, the Internet, and new forms of augment reality, will transform the way students learn. The role of university teachers is already experiencing a significant transformation. In addition, training and educational programs, particularly with the blended format, which combine traditional face-to-face learning with new forms of technology assisted learning may contribute to expansion of personal and professional roles of university teachers (Iniguez, 2016).

Blended learning is a term increasingly used to describe the way e-learning is being combined with traditional classroom methods and independent study to create a new, hybrid teaching methodology. Blended learning mixes various types of event-based activities, including face-to-face classrooms, live e-learning, and self-paced learning. This often is a mix of traditional instructor-led training, synchronous online conferencing or training, asynchronous self-paced study, and structured on-the-job training from an experienced worker or mentor. Blended learning improves students' learning experience by developing their capacity for reflection (Cooner, 2010). Students often view very positively courses in which IC technologies are integrated (Huon et al., 2007). Therefore, the use of different teaching-learning methods enables students to acquire a deeper understanding of the subject and promotes positive perceptions of the teaching methods. Moreover, ICT help to clarify goals and rules in the learning process, as well as provide students with a higher level of independence in the learning process (Ginns et al., 2007). Students may consider these extra resources or activities not only as additional or external to the principal activity, but also as elements that assist in the construction of academic understanding (Orton-Johnson, 2009). In the scope of didactics, blended learning may be considered as a subjective measure of students' outcomes, in other cases, it may also influence the final marks received.

Therefore, blended learning represents a much greater change in basic technique than simply adding computers to classrooms; it represents, in many cases, a fundamental change in the way teachers and students approach the learning experience. This vision is made through by a higher educational institution, which provides innovative learning processes that are responsive to the needs of society. The crucial role of science and technology in enhancing productivity, increasing economic growth and expanding employment has been recognised. There is a need to develop new knowledge and bring the products of new knowledge to the market. Higher education can contribute immensely in this aspect. The linkages between academic 
activities and the development of science and technology have been emphasized by researchers (Rychen, Salganik, 2009).

One of the well-recognized application software in industry is the SAP. It is an acronym for Systemanalyse und Programmentwicklung. It was founded in 1972 by five former IBM engineers in Mannheim BadenWurttemberg in Germany. Its acronym was later changed to mean Systeme, Anwendungen und Produkte in der Datenverarbeitung (System Applications and Products in Data Processing).

SAP is one of the industry players that satisfies companies' requirements of having an integrated software operating on a real-time environment that is more commonly known as enterprise resource planning (ERP). The enterprise resource planning software integrates various functions of a business (inventory and order management; accounting; human resources; customer relationship management) into a one and complete system to streamline processes and information across the entire organization through a shared database. Through this, it offers some degree of synchronized reporting and automation.

SAP Business One is an integrated software that provides a real-time view and manages key business areas such as (a) Accounting and Finance; (b) Sales and Customer Management; (c) Purchasing and Operations; (d) Inventory and Distributions, and (e) Reporting and Distributions. In a report on top software vendors, SAP led the pack with $6 \%$ market share and $\$ 5.3 \mathrm{~B}$ in ERP product revenues, riding on a $23 \%$ jump in license, maintenance and subscription revenues (Pang, 2016).

The integration discussed above describes the formula where enterprise resource planning operates, that is: $E R P=M R P+F A M+S C M+C R M$. Materials Requirement Planning (MRP); Financial and Accounting Management (FAM); Supply Chain Management (CHM) and Customer Relationship Management (CRM) are the different modules of SAP Business One enterprise resource planning. The main thrust of materials requirement planning is the availability of inventory whether raw materials (for production) or finished goods (for sales) in order to avoid shortages and stock out cost. Financial and accounting management addresses the need for proper and fairness of the client financial statements, which is critical for one business. Supply chain management is the oversight of materials, information and finances as they move in such a process: from supplier to manufacturer - to wholesaler - to retailer - to consumer. Supply chain management involves coordinating and integrating these flows within and among companies.

Customer relationship management is a term that refers to practices, strategies and technologies that companies use to manage and analyse customer interactions and data throughout the customer life cycle with the goal to improve business relationships with customers, assisting in customer retention and driving the sales growth.

Due to rapid changes and development, aside from the above mentioned, vendors (providers) provide a variety of packages (modules / solutions) that are mixed and matched according to the needs of companies. The key to these large databases and an integrated enterprise resource planning system is to develop interfaces that will allow file access to these databases (Heizer, 2006).

\section{Hochschule Wismar (HSW) Business Administration courses and their curriculum}

Curriculum is identified to be a central, organizing stance (Portelli, Vilbert, 2002: 39) in the educational process. The Business Administration curriculum is designed to produce graduates that are familiar with business operations and equip them with critical decision- making skills in strategic and executive work necessary for competing in the ever-changing world of global business. The program empowers students with a basic and clear understanding of the functions of every division in a company be it in marketing, finance, operations, human resources and office management. Training in this program emphasises leadership skills and thus prepares students for managerial and supervisory positions.

As reflected in Figure 1, the Business Administration program of Hochschule Wismar is an interdisciplinary and problem-focused program comprised of three integrated elements: (1) basic business; (2) business courses; and (3) professional courses. Each major business course consists of subjects designed to develop critical thinking, problem solving, interpersonal, communication, quantitative and computer skills needed 


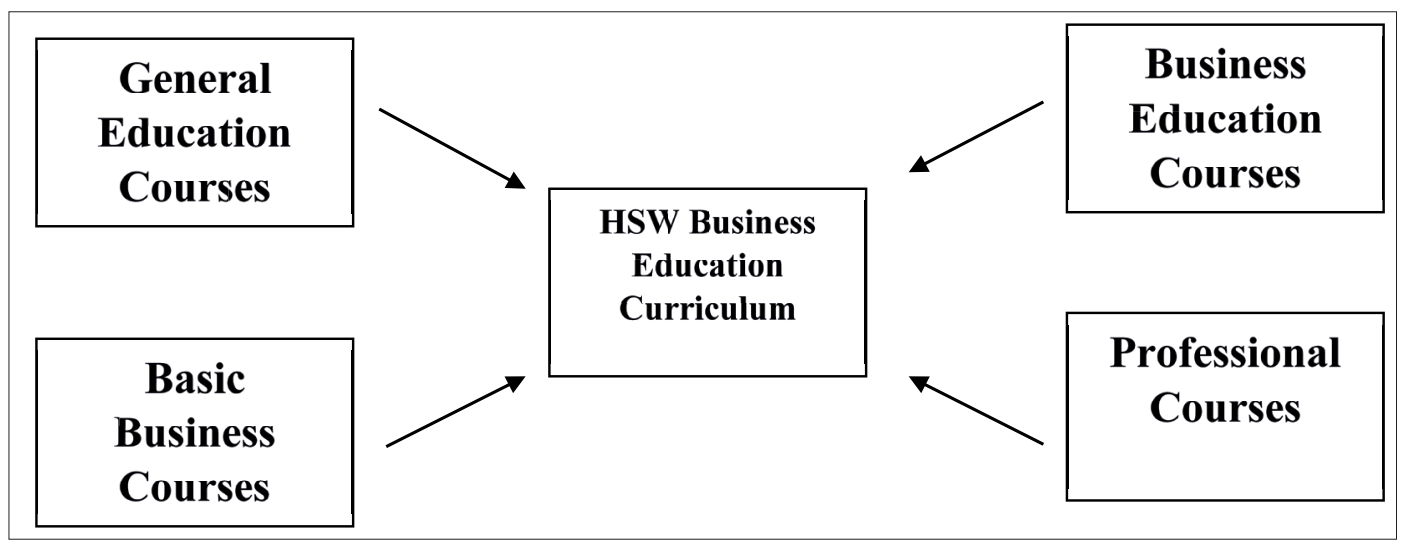

Fig. 1. HSW Business Administration curriculum design

by graduates to successfully serve as leaders in business organizations. The program also addresses contemporary organizational issues such as global competition, continuous quality improvement, good governance and the relationship between organizations and various environmental forces which are key components of the global economy.

This program includes certain levels with their corresponding course descriptions that include the following:

- General Education Courses - these are foundation courses mainly on liberal arts and sciences.

- Basic Business Courses - these are preparation courses in business that include courses on management, accounting, finance and statistics.

- Business Education Courses - these are the core courses in business clustered according to functional areas of business and management.

- Professional Courses - these are electives that include specialization courses on the basis of integration of central management courses.

Wismar Hochschule in addressing the needs of graduates and demands of the industrial sector has collaborated with Fast Track Solutions through its SAP Business One Academy. This segment specifically serves the needs of higher educational institutions. One of the objectives of the integration of the SAP Business One module into business programmes is to equip students with knowledge and skills in enterprise management and resource planning.

\section{SAP Business One: blended learning}

Based on the assessment made, the study conducted within the PEESA II project yielded a positive result such as the different modules of SAP Business One Enterprise Resource Planning matched with the Business Administration curriculum of Hochschule Wismar. The results of the study are presented in Table 1.

As it was observed, the Business Administration curriculum of Hochschule Wismar, is designed in accordance with the minimum requirements of the Commission of Higher Education that was created seeking to improve industry based competencies. As shown in Figure 2, implementation of blended learning through the integration of enterprise resource planning using the SAP Business One (which is enjoying a good market share) complements to the achievement of its objective to produce good, qualified and competent graduates.

To support the graduates of Hochschule Wismar with skills and competencies in handling SAP, a certificate of course completion is issued by Fast Track Solutions as the evidence of the graduate competencies. 
Table 1. Parallel applications of SAP Business One Environment modules for HSW Business Administration curriculum

\begin{tabular}{|c|c|c|c|}
\hline \multirow[t]{2}{*}{ Courses } & \multirow[t]{2}{*}{ Course Description } & \multicolumn{2}{|c|}{ SAP Business One ERP Environment } \\
\hline & & Application & Module \\
\hline $\begin{array}{l}\text { General } \\
\text { Education }\end{array}$ & $\begin{array}{l}\text { Application Software } 1 \\
\text { (with Graphic \& Database Management) }\end{array}$ & ERP - Database Management & \\
\hline Basic Business & $\begin{array}{l}\text { Fundamentals of Accounting } \\
\text { Basic Finance } \\
\text { Principles of Management } \\
\text { Human Resource Management }\end{array}$ & $\begin{array}{l}\text { Fundamentals of Accounting } \\
\text { with Cost Accounting }\end{array}$ & Finance \\
\hline Business & Human Resource Management & HR, Payroll & Finance \\
\hline Education & $\begin{array}{l}\text { Marketing Management } \\
\text { Production \& Operation Management } \\
\text { Inventory Management \& Control } \\
\text { Logistic Management } \\
\text { Financial Management }\end{array}$ & $\begin{array}{l}\text { Sales } \\
\text { Purchasing } \\
\text { Inventory } \\
\text { Production }\end{array}$ & $\begin{array}{l}\text { Materials Requirement } \\
\text { Planning } \\
\text { Supply Chain } \\
\text { Management } \\
\text { Logistic } \\
\text { Customer Relationship } \\
\text { Management }\end{array}$ \\
\hline $\begin{array}{l}\text { Professional } \\
\text { Courses }\end{array}$ & $\begin{array}{l}\text { Professional Salesmanship } \\
\text { Strategic Management } \\
\text { Business Policy } \\
\text { E-Commerce }\end{array}$ & Entrepreneurship & $\begin{array}{l}\text { Logistic } \\
\text { Customer Relationship } \\
\text { Management }\end{array}$ \\
\hline
\end{tabular}

In addition, graduates who have been already engaged in SAP may decide to study and develop their skills further as they may attend different trainings and the certificate examinations, as well as build a career in Information Technology or act as consultants in the field.

Currently, within the PEESA II project, new models of the integration of blended learning into the business curriculum of the Lithuanian and Latvian universities' business study programmes have been elaborated (Zascerinska et al., 2016).

\section{Conclusions}

The theoretical findings of the present research allow concluding that the industry-based higher education institution partnership will serve as a solution in identifying and filling in the gap between the products of higher education institutions and the needs of industry. Therefore, an innovative learning approach enables to make a perfect and suitable curriculum design enhanced by industry based technologies.

Based on a holistic view, this paper has proposed a model for effective implementation of SAP R $/ 3$. The core elements of the model, their expected roles and contributions, the overall integrated aspects which together can result in optimum impact on performance outcomes, have all been scrutinised.

The research question has been formulated as: What is the efficiency of the Business Administration program of Hochschule Wismar in Germany? 


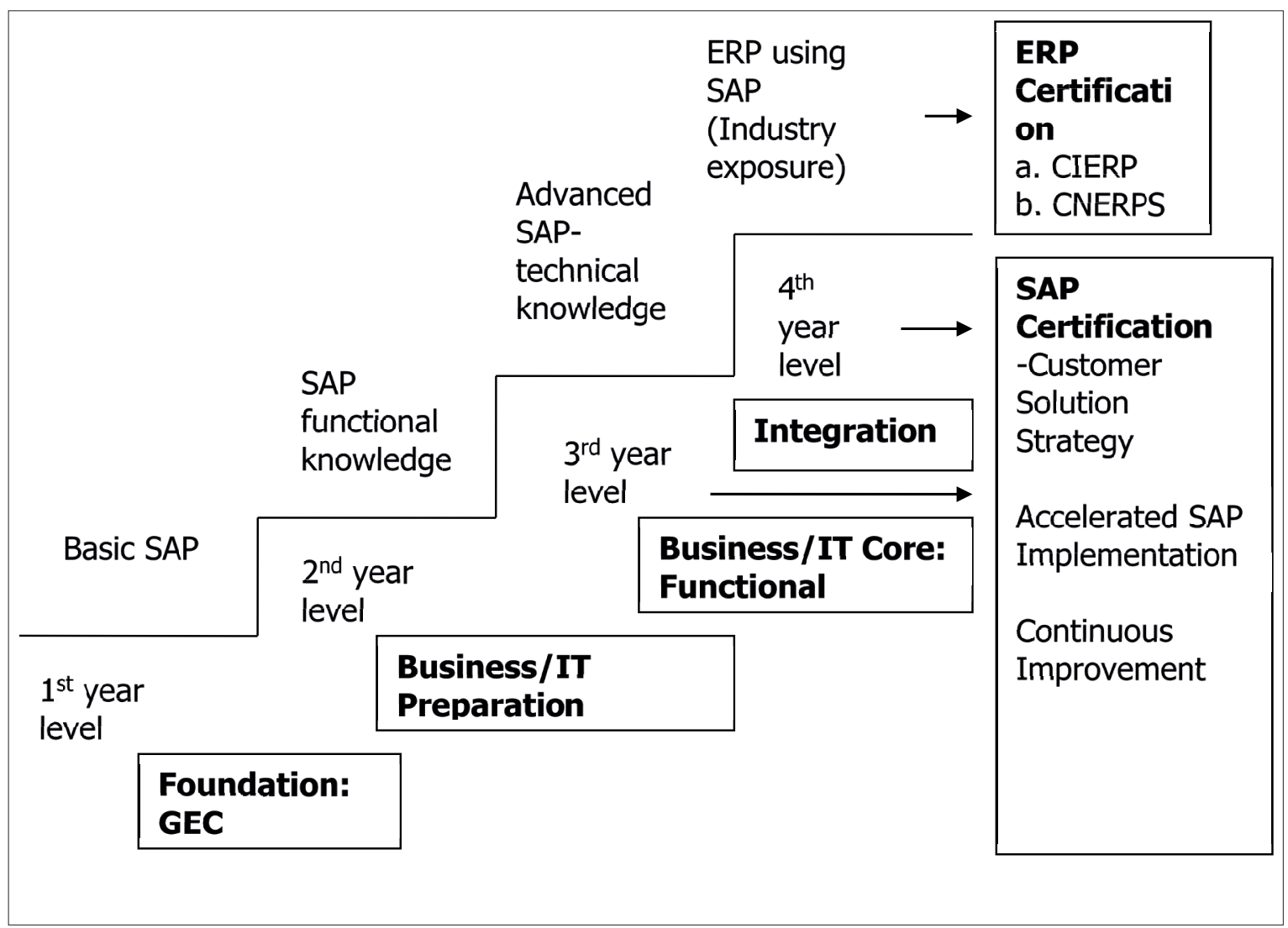

Fig. 2. Schematic diagram of ERP using SAP systems technology

Source: authors

Validity and reliability of the research results have been provided by involving other researchers into several stages of the conducted research (Ahrens, Zaščerinska, 2017). External validity has been revealed by the international co-operation as follows:

- The research preparation has included individual interdisciplinary consultations given by other researchers;

- The present contribution has been worked out in co-operation with international colleagues and assessed by international colleagues;

- The research has been partly presented at international conferences.

However, the present research has limitations. The inter-connections between students' innovative competence, university studies, blended learning and industry-based technologies' learning resources have been set. Another limitation is the empirical study based on one case only, namely Hochschule Wismar in Wismar, Germany. Therefore, the results of the study cannot be representative for the whole area. Nevertheless, the results of the research, namely parallel applications of the SAP Business One Environment Modules for HSW Business Curriculum, may be used as a basis for the analysis of burstiness in the e-business process. If the results of other cases had been available for analysis, different results could have been attained. Thus, there is a possibility to continue the study.

Investigation on further functions of the SAP Business One Environment Modules in university studies are the focus of future research. Further research tends to search for application of the SAP Business One Environment Modules in the curriculum of other higher education institutions, particularly in Lithuania and 
Latvia. Empirical studies on application of SAP Business One Environment Modules for HSW Business Curriculum are to be implemented. The authors proposed relevant methods, tools and techniques for the analysis of application of SAP Business One Environment Modules for HSW Business Curriculum. Also, a comparative research analysis on the application of SAP Business One Environment Modules for HSW Business Curriculum could be carried out in the future.

\section{Acknowledgements}

This paper has been prepared within the project „Hochschulkooperation „Energy Efficiency in Southern Africa" supported by Bundesministerium für Bildung und Forschung, Germany. DAAD DLR Projektträger Reference Number 01DG16009. Duration: December 1, 2016 - January 31, 2018. Coordinator: Hochschule Flensburg, Germany.

\section{References}

Ahrens, A., Bassus, O., Zaščerinska, J. (2013). Bi-professional Curriculum in Higher Education: Context Analysis. Proceedings of 6th ICEBE International Conference on Engineering and Business Education Innovation, Entrepreneurship and Sustainability. Windhoek, 7-10 October 2013, p. 101-107.

Ahrens, A., Zascerinska, J., Bassus, O. (2010). Enterprise 2.0 in Engineering and Business Education: Education and Business Students' View. Proceedings of the 3rd International Conference on Innovation and Entrepreneurship and its implications in Engineering and Business Education. Available at: http://files.eric.ed.gov/fulltext/ED529857.pdf [Accessed: February 23, 2017].

Ahrens, A., Zaščerinska, J. (2017). E-Shop Visitors' Burstiness as a Predictor of Performance - The Case of eBay. ICETE 2017 Proceedings of the $14^{\text {th }}$ International Joint Conference on e-Business and Telecommunications Volume 2: ICE-B, Madrid, Spain, July 24-26, 2017, p. 78-82. Published by SCITEPRESS - Science and Technology Publications, Lda. Printed in Portugal.

CHED (2005). Medium-Term Development Plan for Higher Education: 2005-2010.

Cohen, L., Manion, L., Morrison, K. (2007). Research Methods in Education. New York: Routledge Education, USA.

Cooner, T. S. (2010). Creating Opportunities for Students in Large Cohorts to Reflect in and on Practice: Lessons Learnt from a Formative Evaluation of Students' Experiences of a Technology-Enhanced Blended Learning Design. British Journal of Educational Technology, Vol. 41 (2), p. 271-286.

Customer Relationship Management. (2014). Available at: http://searchcrm.techtarget.com/definition/CRM [Accessed: February 23, 2017].

Entrepreneurship in Education in Baltic Sea Region. (2015). Retrieved 28/11/2015 from http://socialinnovation.lv/en/ educational-materials-of-social-entrepreneurship-development-in-the-baltic-sea-region/

Entrepreneurship in Latvia and Other Baltic States: Results from the Global Entrepreneurship Monitor. (2013). Retrieved 28/11/2015 from http://freepolicybriefs.org/2013/11/04/entrepreneurship-in-latvia-and-other-baltic-statesresults-from-the-global-entrepreneurship-monitor/

Ginns, M., Prosser, S., Barrie, M. (2007). Students' Perceptions of Teaching Quality in Higher Education: The Perspective of Currently Enrolled Students. Studies in Higher Education, Vol. 32 (5), p. 603-615.

Heizer, J. H. (2006). Operation Management. New Jersey: Prentice Hall.

Huon, I., Bucksch, S. (2016). Approaches for bridging research an industry. Archives of Business Research, Vol. 4(1), p. 209-215.

Iniguez, S. (2016). Major Trends in Business Education. Available at: http://www.mba-journal.de/major-trends-in-business-education/ [Accessed: February 23, 2017].

Kohlbacher, F. (2005). The Use of Qualitative Content Analysis in Case Study Research. Forum Qualitative Sozialforschung / Forum: Qualitative Social Research, Vol. 7(1), Art. 21. Available at: http://nbn-resolving.de/ urn:nbn:de:0114-fqs0601211 [Accessed: February 23, 2017].

Nielsen, P. (2006). Innovation, Employment and Competence Development. Invited paper presented at the 14th. International Industrial Relation Associations World Conference, Lima. Aalborg University: Centre for Labor Market Studies.

Orton-Johnson, K. (2009). Exploring Student Non-Use of Blended Learning. British Journal of Educational Technology, Vol. 40 (5), p. 837-847.

Pang, A. (2016). Top 10 ERP Software Vendors and Market Forecast 2015-2020. Available at: https://www.appsruntheworld.com/top-10-erp-software-vendors-and-market-forecast-2015-2020/ [Accessed: February 23, 2017]. 
Portelli, J. P., Vilbert, A. B. A. (2002). Curriculum of Life. Education Canada, Vol. 42 (2), p. 36-39. Canadian Education Association.

Rychen, D. S., Salganik, L. H. (2001). Defining and Selecting Key Competencies. Cambridge, Massachusetts: Hogrefe. Selzer, K., Bentley, T. (1999). The Creative Age. London: Demos.

Storz, C., Schaefer, S. (2011). Institutional Diversity and Innovation. Continuing and Emerging Patterns in Japan and China. Oxon: Routledge.

Supply Chain Management (2010). Available at: http://searchmanufacturingerp.techtarget.com/definition/supplychain-management [Accessed: February 23, 2017].

Taylor, P. C., Medina, M. N. D. (2011). Educational Research Paradigms: From Positivism to Pluralism. College Research Journal, Vol. 1 (1), p. 9-23.

What is ERP? Available at: http://www.netsuite.com/portal/resource/articles/erp/what-is-erp.shtml [Accessed: February 23,2017$]$.

Yin, R. K. (2003). Case study research, design and methods. 3rd ed., Vol. 5. Thousand Oaks: Sage.

Zainal, Z. (2007). Case Study as a Research Method. Jurnal Kemanusiaan bil. 9.

Zaščerinska, J., Zaščerinskis, M., Aleksejeva, L., Andreeva, N. (2016). An Approach to Hybrid Business Management: Theoretical Modelling. Proceedings of the 17th Student and Teacher Scientific and Practical Conference National Economy Development: Problems and Solutions, p. 53-57. Rēzekne: Rēzeknes Tehnoloğiju akadēmijas Izdevniecība.

\title{
ST UDENTU INOVATYVUMO KOMPETENCIJOS PLE் TOJIMAS UNIVERSITETINÉSE STUDIJOSE (SOCIALINIU MOKSLU KRYPTIES), NAUDOJANT VERSLO IR GAMYBOS SEKTORIAUS TECHNOLOGIJŲ MOKYMOSI IŠTEKLIUS
}

\author{
Andreas Ahrens, JuliJa Melnikova, JeĻena ZašČErinsKa \\ Wismaro aukštoji mokykla (Vokietija), Klaipedos universitetas (Lietuva), Edukologijos ir tyrimų centras (Latvija)
}

\section{Santrauka}

Šio straipsnio tikslas - atskleisti „Pirmenybinio sprendinio Verslo valdymo kompiuterių programa“ (angl. Fast Track Solution SAP Business One) modulio taikymo galimybes universitetinių studijų verslo vadybos programoje. Straipsnis parengtas vykdant projektą „PEESA II“ (Aukštojo mokslo skaitmeninimo galimybės). Vykdant projektą i Wismaro universiteto verslo vadybos studijų programą integruotas „Verslo valdymo kompiuterių programa“ modulis. Ši mokymos(-si) prieiga grindžiama mišraus mokymosi metodologija, todèl straipsnyje atskleidžiami esminiai tokio mokymosi principai. Mišrus mokymas(-is) apibrèžiamas kaip i̇vairių informacinių ir komunikacinių technologijų derinys, siekiant parengti geriausią specifinei auditorijai mokymo(-si) programą: ịvairūs e. mokymo(-si) elementai derinami su tiesioginėmis dėstytojo paskaitomis, konsultacijomis. Teigiama, kad mišraus mokymosi metodologiniai principai tiesiogiai veikia mokymosi proceso efektyvumą ir studentų akademinius pasiekimus.

„Pirmenybinio sprendinio Verslo valdymo kompiuteriu programa“ yra integruota programinè ịranga, apimanti šias pagrindines verslo sritis: a) apskaita ir finansai; b) pardavimai ir klientų valdymas; c) pirkimai ir operacijos; d) inventorizacija ir paskirstymas ir e) ataskaitų teikimas ir paskirstymas. Šie informacinemis technologijomis pagrịsti mokymosi tikslai pasirinkti kaip geriausiai atitinkantys verslo ir gamybos sektoriaus poreikius (Pang, 2016).

Taikydami „Verslo valdymo kompiuterių programa“ modeli mokymosi procese studentai igyja žinių ir supratimo apie tai, kaip sąveikauja ir integruojasi įvairios verslo sritys, o informacinių technologijų infrastruktūra supaprastina verslo operacijas. Be to, šiame straipsnyje pristatomi „Verslo valdymo kompiuterių 
programa“ moduliai, kuriuos galima būtų taikyti verslo vadybos studijų programoms universitete optimizuoti, siekiant patenkinti verslo ir gamybos poreikius. Mišrus mokymasis, kaip mokymosi metodas, taikant „Verslo valdymo kompiuteriu programa“ modulius, tenkina verslo ir gamybos sektoriaus kompetenciju poreiki, siekiant glaudžiau bendradarbiauti su aukštuoju mokslu. Teorinès žinios ir praktinė patirtis, igytos mišraus mokymosi būdu, suteiks verslo vadybos programų studentams konkurencinį pranašumą darbo rinkoje ir plètos jų inovatyvumo kompetenciją.

Tyrime taikyta aprašomoji interpretacinè metodologija. Wismaro universitete atliktas eksperimentas ir surinkti empiriniai duomenys apie „Verslo valdymo kompiuterių programa“ modulių integravimą i verslo vadybos studijų programos turinị leido formuluoti rekomendacijas kitų šalių universitetams (taip pat Lietuvos ir Latvijos), kaip optimizuoti verslo vadybos studiju programas integruojant naujausias informacines technologijas.

PAGRINDINIAI ŽODŽIAI: Pirmenybinio sprendinio Verslo valdymo kompiuteriu programa, verslo ir vadybos studiju programu ugdymo turinys, $i$ verslo ir gamybos poreikius nukreiptas mokymasis, mišrus mokymasis.

JEL KLASIFIKACIJA: M10; M15; I25

Received: 2017.12.06

Reviesed: 2017.12.28

Accepted: 2018.01 .26 